\title{
Entrepreneurship among parents
}

\author{
Lars Kolvereid(D
}

Correspondence:

lars.kolvereid@nord.no

Nord University Business School,

NO-8049 Bodø, Norway

\begin{abstract}
The present study investigates the relationship between the number of children in the household and mothers and fathers' propensity to become and remain owners of limited liability businesses. We started by identifying all full-time employed taxpayers in Norway in 2004 between 25 and 50 years of age. In this study, we look at the relationship between the number of children in the household and the propensity of these non-entrepreneurs to become and remain business owners from 2005 to 2016. For both sexes, the results show a positive and linear relationship between the number of children at home and business ownership and a U-shaped relationship between the size of the household brood and exit from business ownership.
\end{abstract}

Keywords: Children, Mothers, Fathers, Parents, Entrepreneurship

\section{Background}

The purpose of this research note is to answer the following research questions: (1) What is the relationship between the number of children in the household and the propensity of fathers and mothers to become business owners? (2) What is the relationship between the number of children in the household on the propensity of fathers and mothers to continue or discontinue their careers as business owners?

Understanding the relationship between fertility and occupational status choice among women and men is important for theoretical and practical purposes. Knowing the relationship between the number of children in the household and the decision to become an entrepreneur has implications for public policy as well as business owners (MacPherson, 1988; Noseleit 2014). Governments in many western countries want to promote entrepreneurship and simultaneously encourage families to have more children, yet we do not know for certain if these goals are in conflict with each other. In addition, revealing the association between the number of children at home and exit from business ownership among women and men has implications for theory, prospective entrepreneurs, and policy makers. For example, if it is more difficult for mothers and fathers in large families to survive as business owners, governments could consider support systems to help large families take care of their children or their businesses.

The starting point of the present study is all non-entrepreneurs in Norway who were between 25 and 50 years of age and full-time employed in 2004. Some of these individuals became majority owners of limited liability businesses between 2005 and 2015. In 2016, some of these individuals were still business owners, while others had exited from business ownership. Thus, the dependent variable in this research is majority

(C) The Author(s). 2018 Open Access This article is distributed under the terms of the Creative Commons Attribution 4.0 International License (http://creativecommons.org/licenses/by/4.0/), which permits unrestricted use, distribution, and reproduction in any medium, provided you give appropriate credit to the original author(s) and the source, provide a link to the Creative Commons license, and indicate if changes were made. 
ownership in at least one business. As each firm has a lead entrepreneur, it is possible to study how gender and the number of children in the household influence the decision to become and remain business owners. The sample consists of all individuals in the country who in 2004 satisfied the selection criteria and among them all who became majority owners of limited liability businesses between 2005 and 2016 .

This study has several novel contributions. The relationship between the number of children at home and the propensity to become self-employed has previously been addressed in a number of studies. As far as this relationship is concerned, the novelty of the present research is primarily methodological. Only with one exception (Joona 2017), all previous studies on children and self-employment have used data from population surveys. Such surveys are prone to error with regard to sample representativeness and other biases. Most previous research on children and self-employment is cross-sectional. Although some studies have used population surveys from multiple years, most of them are not truly longitudinal and fail to follow the same individuals over time. Previous studies typically use a sample of the entire adult population in the country and cannot specify a year of entry into self-employment. The present study starts with all full-time employed adults (i.e., non-entrepreneurs) in a country.

Only a handful of studies have studied the relationship between the number of children at home and survival as a business owner. In these studies, the sample sizes have been too small to reveal the true relationship between the number of children in the household and survival as a business owner among women and men. Previous studies have also assumed a linear relationship between the number of children at home and the probability to exit from entrepreneurship. In the present study, we argue and find empirical support for a U-shaped non-linear relationship between the number of children at home and exit from business ownership.

\section{Literature review and hypotheses}

Aldrich and Cliff (2003) suggested a family embeddedness perspective of entrepreneurship. They developed a model where family system characteristics influence the venture creation process, which again influence new venture outcomes. The number of children in the household is an important aspect of the family structure. Aldrich and Cliff (2003) argued that an increasing number of children in the household have positive effects on several aspects of the venture creation process, including opportunity emergence, opportunity recognition, venture creation decisions, and resource mobilization. In addition to being a resource for the family, children expand the network of their parents through facilitating acquaintance to parents of classmates and peers in extracurricular activities, such as sports, music, or membership in voluntary organizations. The family embeddedness perspective predicts that the number of children in the household is positively associated with the propensity to start a business and entry into self-employment.

From 1992 to 2017, several studies have found a positive relationship between the number of children at home and self-employment or business ownership rates in a range of countries. Table 1 shows a summary of these studies.

All the studies summarized in Table 1 found that having children increases the likelihood of self-employment among women. With one exception (Arai 2000), the studies also found that having children increases the odds of self-employment among men. 


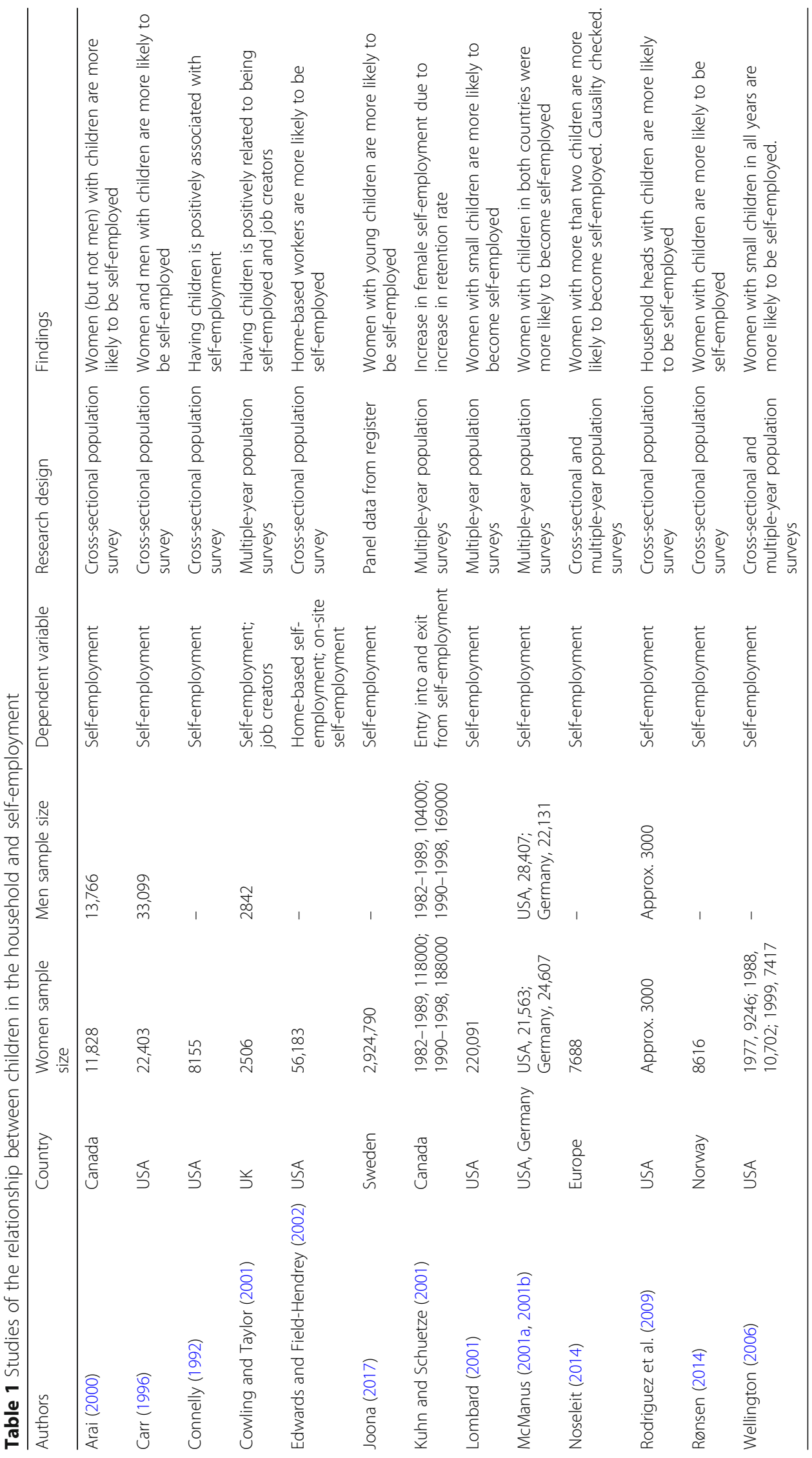


All studies in Table 1 are from rich countries in North America and Western Europe. Except Joona (2017), all studies have used population surveys, where participants report their own employment status. While some studies have used population surveys from multiple years, most of them are not longitudinal at the individual level of analysis. One exception is the study of Kuhn and Schuetze (2001), in which they reported to have 2-year panel data from each individual. With the exception of Arai (2000), all studies have reported a positive association between the number of children at home and the likelihood of being self-employed for both women and men.

Several previous studies on children in the household and self-employment do not mention explicitly how self-employment is measured. Many studies do not require respondents to be business owners but classify participants based on their earnings a particular year received from wage employment or from self-employment (e.g., Caputo and Dolinsky 1998). Asking respondents to classify their own employment status is a questionable practice since people conceive self-employment differently. Even national and OECD statistics of self-employment must be adjusted to obtain comparable figures for business ownership across countries (Noorderhaven et al. 2004). However, the use of different definitions makes the finding in most studies regarding the positive association between children in the household and self-employment more credible and generalizable.

Since Noseleit (2014) studied women only, he urged for future studies on the topic since "children may play an important role in the observed difference in male and female self-employment rates" (Noseleit 2014, p. 563). The family context may have different impacts for men and women (Gundry et al. 2014). There is therefore a need to study the relationship between the number of children at home and self-employment or business start-up rates among men and women separately. Drawing on theory and past empirical findings, we formulate separate hypotheses for men and women:

H1a. Among men, the number of children at home relates positively and linearly to the propensity to become a business owner.

H1b. Among women, the number of children at home relates positively and linearly to the propensity to become a business owner.

According to Becker's (1965) theory of the allocation of time, households in richer countries forfeit income in order to obtain additional psychic utility, such as increased leisure time, a more pleasant job, or increased time for childcare. As he points out, childcare is a time-intensive activity that is not "productive" in terms of earnings and uses many hours, which parents could use to work. Unlike other consumer durables, children are time-intensive and the time allocated to childcare is likely to increase with the number of children in the household (Friedman et al. 1994).

Some scholars expect a positive and linear relationship between the number of children in the household and the likelihood of exit from business ownership. Olson et al. (2003, p. 659) argue that "children are expensive, and if the business must be able to support the family adequately for the owner to perceive it as successful, each additional child may raise the threshold of what is perceived as success." Following this reasoning, Justo and DeTienne (2008) argue that entrepreneurs with children have higher opportunity costs and should be more likely to voluntarily exit their businesses.

There are, however, reasons to believe that the relationship between the size of the household and exit from entrepreneurship is not linear but U-shaped. Small families 
have more flexibility than larger families. In small families, it is easier to make decisions that concern work as well as other issues. Singles with no children have no other person in the household to consider and therefore have the highest flexibility. Families with two or more adults and a high number of children have the lowest flexibility.

Adults in households have to consider the other individuals in the household when making decisions about housing, re-location, employment, entrepreneurship, schooling, leisure, hobbies, and many other choices in life. The larger the family, the more common is sickness in the family and the more difficult it is to make decisions and to reach agreement about issues that concern the family. Especially in poor countries and among immigrants in rich countries, an increasing number of siblings is associated with poverty and can act as a proxy for family wealth (Patrinos and Psacharopoulos 1997). The higher the number of children, the more time is spent on childcare. In large families, it is more difficult to find time for the business, everything else being equal. ${ }^{1}$

Employment opportunities and other opportunities (let us sail around the world) that entrepreneurs in larger families would not consider can be tempting for entrepreneurs in small families. Increasing family size is associated with declining mobility in the labor market, particularly if the new job requires a re-location. For large families, moving is more problematic, because they are more likely to own their own home and because they have to take into account the wellbeing of the children in the household, including their classmates and friends (Halket and Vasudev 2014).

Large families have to spend a lot of time on childcare and the flexibility in such families is low. Small families have high flexibility and do not have to spend much time in childcare. Therefore, entrepreneurs in large firms will tend to leave their entrepreneurial careers due to time constraints, and entrepreneurs in small family will tend to exit from business ownership because they are tempted by employment opportunities and other opportunities that entrepreneurs in larger families would not consider. Entrepreneurs in medium-sized families are likely to have the highest endurance. The responsibility for the family prevents them from pursuing endeavors entrepreneurs in small families more easily can pursue. Simultaneously, adults in medium-sized households have more time at their disposal for pursuing entrepreneurial endeavors than adults in large households. In summary, these arguments lead us to argue that that the relationship between the number of children at home and exit from business ownership is likely to be non-linear and U-shaped.

Only a handful studies have investigated the relationship between the number of children in the household and survival as self-employed or business owner. Using data from the Global Entrepreneurship Monitor, Justo and DeTienne (2008) failed to find a significant association between the number of children at home and firm exit. In another study using GEM data from Spain, Justo et al. (2015) did not find significant correlations between the number of children and involuntary exit, exit for personal reasons, or exit for other professional/financial opportunities. It is possible that the samples of Justa and associates were not large enough to reveal the true relationship between children and exit from entrepreneurship. As the sample size is much larger in the present circumstances, we hypothesize:

H2a. Among male entrepreneurs, there is a U-shaped relationship between the number of children at home and the propensity to exit from business ownership.

In western countries, mothers spend more time on childcare than fathers (Craig and Mullan 2011). Men and women tend to allocate their time differently, and men have 
more leisure than women (Aguiar and Hurst 2007). As it is not clear how such differences in the allocation of time between the genders influence the propensity to exit from business ownership, we use the same hypothesis for men and women.

$\mathrm{H} 2 \mathrm{~b}$. Among female entrepreneurs, there is a U-shaped relationship between the number of children at home and the propensity to exit from business ownership.

\section{Methods}

The tax authority in Norway provided the data used in this study. The initial step in the data collection process involved the identification of taxpayers in Norway between 25 and 50 years of age in 2004. This age interval is the same as that Folta et al. (2010) used in their study of hybrid entrepreneurs and was chosen because individuals between 25 and 50 years of age have the highest propensity for entrepreneurship. The year 2004 was the earliest year the tax authority had complete data of shareholders in limited liability businesses. The first step was to identify all full-time employed adults who had no roles in business in 2004. This was done by searching in tax records and databases containing information about business ownership and roles in businesses for the entire population in the country. According to one of the main labor unions in the country, the minimum annual salary for full-time employees in 2004 was NOK 196,000 (Fagforbundet 2004). In order to remove part-time employees, we therefore required individuals to have an income in 2004 above this threshold. Further, we removed individuals who in 2004 were sole proprietors, business partners in partnerships, majority shareholders, or board members in limited liability businesses.

The next step in the data collection process was to identify all businesses in Norway where these individuals obtained a majority stake (i.e., more than $50 \%$ ) between 2005 and 2016. We focused on limited liability businesses because they have to meet a minimum capital requirement, are obliged to submit annual accounts to the tax authority and they have to report any important changes in the business, including changes in ownership, top manager, or board composition. For these reasons, limited liability businesses are usually larger and less likely to be part-time operations or dormant firms than sole proprietorships and partnerships. We selected majority owners to be able to link personal characteristics of the owners to the firms. This procedure also made sure that there is only one self-employed person in each business. The Norwegian tax authority has databases for shareholders in limited liability businesses every year from 2005 to 2016 making it possible to trace business owners and exit from business ownership.

\section{Measures}

In the sample, 431 individuals had missing value for the number of children under 18 years old in the household, ${ }^{2}$ reducing the number of individuals in the sample from 686,043 to 685,616 . The average number of children under 18 years of age in the household was 1.62 (range $0-11$ ). In the sample, $12.2 \%$ of households had no children, $32.8 \%$ one child, $39.0 \%$ two children, $13.7 \%$ three children, and $3.4 \%$ four or more children.

From 2005 to the end of 2016, 30,595 of the 686,043 individuals (4.5\%) had become majority owners of at least one business. We coded this variable as 1 for owners, and 0 
for non-owners. We removed nine owners from the analysis since we had no information about their number of children.

From 2005 to 2015, 6020 of the owners had given up their entrepreneurial career and were no longer owners in 2016. We defined previous owners as discouraged entrepreneurs and persisting owners as entrepreneurs who still were owners in 2016. The persisting owners include novices as well as serial and portfolio entrepreneurs (Lechner et al. 2016), but we excluded novice entrepreneurs who became business owners for the first time in 2016. The sample contains of 22,107 persisting entrepreneurs and 6020 discouraged entrepreneurs. This variable is coded 1 for discouraged entrepreneurs and 0 for persisting entrepreneurs.

In the multivariate testing of hypotheses, we include five control variables that may influence the propensity to become and remain a business owner. These variables are as follows: (1) Age (ranging from 25 to 50 years in 2004). (2) Personal income in 2004 before tax (measured in NOK). (3) Employment in a corporation in $2004(1=$ yes, $0=$ no). We included this control variable because most corporations in the country are privately owned and because we study ownership of such businesses. (4) Residence in Oslo ( $1=$ yes, $0=$ no). Oslo is the capital of Norway and with 673,000 inhabitants in 2018 by far the largest city in the country. (5) Born in Norway ( $1=y e s, 0=$ no). This variable was added to control for possible differences in entrepreneurship between Norwegians and immigrants.

\section{Statistical analysis}

We test the hypotheses in two different ways. First, we use simple bivariate cross-tabulation and chi-square tests to investigate the relationship between the number of children in the household (coded $0,1,2,3$, and 4 or more) and the propensity to become and remain a business owner. We then carry out more rigorous tests of the hypotheses where we include relevant control variables in logistic regressions.

In the multivariate analyses, the number of children in the household is a continuous variable ranging from 0 to 11 . We also entered the number of children squared into the logistic regression equations. For hypotheses $1 \mathrm{a}$ and $1 \mathrm{~b}$ regarding entry into business ownership to hold, the number of children should have a positive and statistically significant effect on entry into business ownership (i.e., $\operatorname{Exp}(\mathrm{B})$ should be significant and larger than 1), and the number of children squared should be statistically insignificant. Such a result will show that the number of children in the household is positively and linearly associated with entry into business ownership. For hypotheses $2 \mathrm{a}$ and $2 \mathrm{~b}$ regarding exit from business ownership to hold, the number of children in the household should have a negative and statistically significant effect on exit from business ownership (i.e., $\operatorname{Exp}(\mathrm{B})$ should be significant and smaller than 1), and the number of children squared should be positive and statistically significant (i.e., $\operatorname{Exp}(B)$ should be significant and larger than 1). Such a result would indicate a U-shaped relationship between the number of children and exit from business ownership.

\section{Results}

Bivariate analysis

Table 2 and Fig. 1 show the relationship between the propensity to start a business among mothers and fathers broken down by the number of children. The proportion 
Table 2 Number of children and businesses ownership among parents

\begin{tabular}{|c|c|c|c|c|c|c|}
\hline \multirow{2}{*}{$\begin{array}{l}\text { Number } \\
\text { of children }\end{array}$} & \multicolumn{2}{|c|}{ Mothers $(n=302,389)$} & \multicolumn{2}{|c|}{ Fathers $(n=383,223)$} & \multicolumn{2}{|l|}{ Total $(n=685,612)$} \\
\hline & $\begin{array}{l}\text { Non- } \\
\text { entrepreneurs }\end{array}$ & Entrepreneurs & $\begin{array}{l}\text { Non- } \\
\text { entrepreneurs }\end{array}$ & Entrepreneurs & Non-entrepreneurs & Entrepreneurs \\
\hline 0 & $99.0 \%$ & $1.0 \%$ & $95.7 \%$ & $4.3 \%$ & $97.7 \%$ & $2.3 \%$ \\
\hline 1 & $98.4 \%$ & $1.6 \%$ & $93.7 \%$ & $6.3 \%$ & $95.8 \%$ & $4.2 \%$ \\
\hline 2 & $98.1 \%$ & $1.9 \%$ & $92.9 \%$ & $7.1 \%$ & $95.1 \%$ & $4.9 \%$ \\
\hline 3 & $98.1 \%$ & $1.9 \%$ & $92.4 \%$ & $7.6 \%$ & $94.6 \%$ & $5.4 \%$ \\
\hline $4+$ & $98.0 \%$ & $2.0 \%$ & $92.6 \%$ & $7.4 \%$ & $94.2 \%$ & $5.8 \%$ \\
\hline Total & $98.3 \%$ & $1.7 \%$ & $93.3 \%$ & $6.7 \%$ & $95.5 \%$ & $4.5 \%$ \\
\hline Chi-square & $175.7^{* * *}$ & & $466.5^{* * *}$ & & $1531.3^{* * *}$ & \\
\hline
\end{tabular}

***p $\leq .001$

of female owners is only $16.4 \%$, reflecting that the table shows majority owners in limited liability businesses and does not include sole proprietorships or partnerships where the proportion of female entrepreneurs is much higher (Statistics Norway 2018). As Table 2 shows, there is a clear tendency that the odds of becoming an entrepreneur increase with the number of children. This effect is true for both men and women but appears to be slightly stronger for fathers than for mothers. These findings give preliminary support for hypotheses $1 \mathrm{a}$ and $1 \mathrm{~b}$. The bivariate analyses show that the association between the number of children at home and the odds of becoming a business owner is positive, but multivariate analyses are needed to check if this relationship is also linear.

The next step in the analysis was to investigate the relationship between the number of children at home and the odds of continuing or discontinuing the career as entrepreneurs. The proportion of discouraged women entrepreneurs is $26.6 \%$ compared to a proportion of $20.3 \%$ male discouraged entrepreneurs. This result supports previous findings indicating that the mortality rate is higher for business owned by women than by men (Kalnins and Williams 2014). The average age of discouraged entrepreneurs is

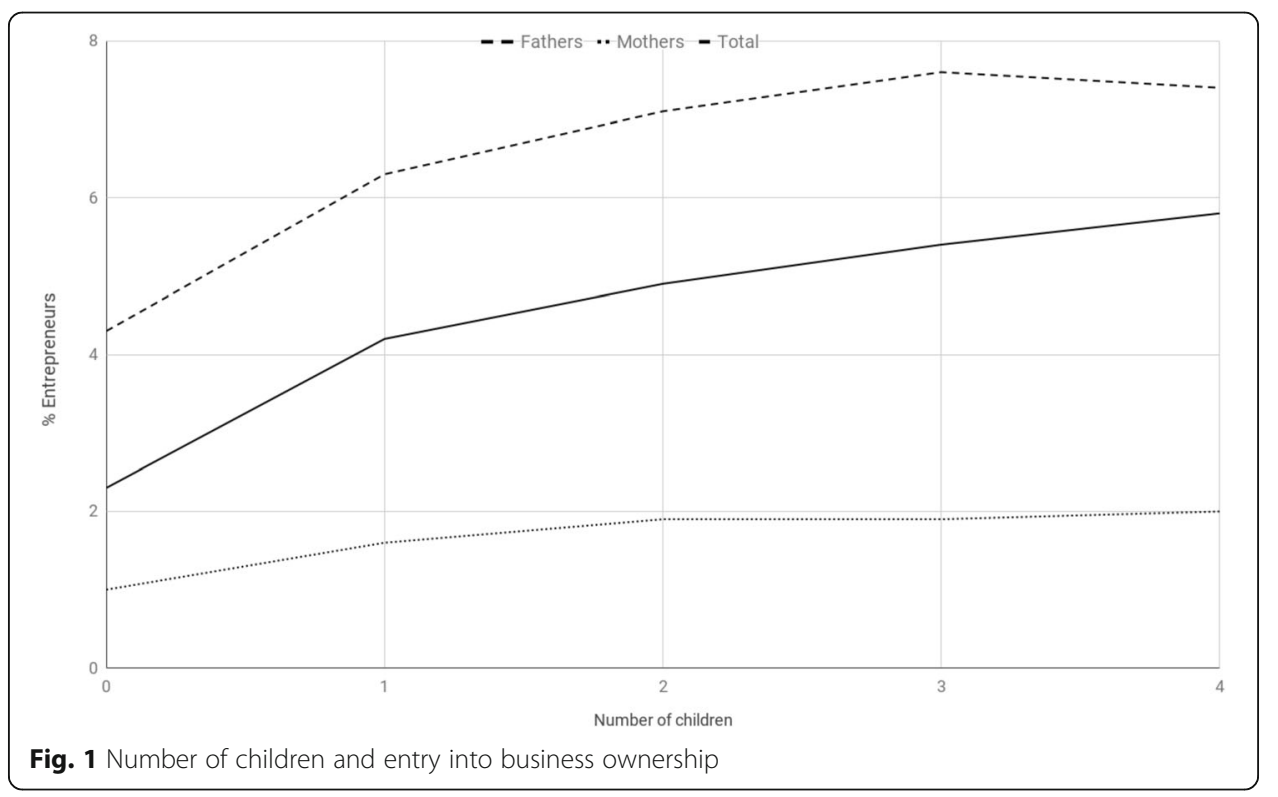


38.7 years and among persisting entrepreneurs 38.5 years (due to the large sample, this age difference is statistically significant at $p \leq .05$ ).

Table 3 and Fig. 2 show how the proportion of discouraged and persisting entrepreneurs vary with gender and the number of children. Entrepreneurs without children are far more likely to give up their entrepreneurial career than entrepreneurs who have children. This appears to be true for both women and men, but among childless adults, women are more likely than men to exit from business ownership. Among women as well as men with children, the proportion of discouraged entrepreneurs is lowest among individuals with two or three children. Owners with only one child or with four children or more are more likely to discontinue their career as entrepreneurs. Hypotheses $2 \mathrm{a}$ and $2 \mathrm{~b}$ receive preliminary support, but multivariate tests are required to check the statistical significance of this U-shaped relationship.

\section{Multivariate analysis}

Table 4 shows descriptive statistics and correlations among the analysis variables. The correlation between the number of children in the household and business ownership is positive and statistically significant at $p \leq .01(r=.041)$. All control variables are significantly correlated with business ownership as well as exit from business ownership. None of the correlations are large enough to warrant any concern for multicolinearity in the regressions.

To test hypotheses $1 \mathrm{a}$ and $1 \mathrm{~b}$, we entered the control variables, the number of children, and the number of children squared into the equations. Table 5 illustrates the results from the logistic regressions. The first column in Table 5 shows the result for women, the second column the result for men, and the third column the result for the entire sample. In all three equations, the number of children is positively and significantly associated with the odds of becoming a business owner and the number of children squared is insignificant. This indicates that the number of children is positively and linearly associated with the odds of entry into business ownership for women, for men, and for the entire sample. Hypotheses $1 \mathrm{a}$ and $1 \mathrm{~b}$ are supported.

Hypotheses $2 \mathrm{a}$ and $2 \mathrm{~b}$ concerning the odds of exit from business ownership were tested in the same way. With exit from business ownership as the dependent variable, we entered the control variables, the number of children, and the number of children squared into the equations. Table 6 illustrates the results. The first column in Table 6

Table 3 Number of children and exit from business ownership among parents

\begin{tabular}{|c|c|c|c|c|c|c|}
\hline \multirow{2}{*}{$\begin{array}{l}\text { Number } \\
\text { of children }\end{array}$} & \multicolumn{2}{|c|}{ Mothers $(n=4473)$} & \multicolumn{2}{|c|}{ Fathers $(n=23,354)$} & \multicolumn{2}{|c|}{ Total $(n=28,127)$} \\
\hline & $\begin{array}{l}\text { Persisting } \\
\text { entrepreneurs }\end{array}$ & $\begin{array}{l}\text { Discouraged } \\
\text { entrepreneurs }\end{array}$ & $\begin{array}{l}\text { Persisting } \\
\text { entrepreneurs }\end{array}$ & $\begin{array}{l}\text { Discouraged } \\
\text { entrepreneurs }\end{array}$ & $\begin{array}{l}\text { Persisting } \\
\text { entrepreneurs }\end{array}$ & $\begin{array}{l}\text { Discouraged } \\
\text { entrepreneurs }\end{array}$ \\
\hline 0 & $66.9 \%$ & $33.1 \%$ & $77.7 \%$ & $23.3 \%$ & $74.6 \%$ & $25.4 \%$ \\
\hline 1 & $73.8 \%$ & $26.2 \%$ & $79.0 \%$ & $21.0 \%$ & $78.1 \%$ & $21.9 \%$ \\
\hline 2 & $74.6 \%$ & $25.4 \%$ & $80.6 \%$ & $19.4 \%$ & $79.6 \%$ & $20.4 \%$ \\
\hline 3 & $75.0 \%$ & $25.0 \%$ & $79.5 \%$ & $20.5 \%$ & $78.8 \%$ & $21.2 \%$ \\
\hline 4 & $72.2 \%$ & $25.8 \%$ & $77.4 \%$ & $22.6 \%$ & $76.4 \%$ & $23.6 \%$ \\
\hline Total & $73.6 \%$ & $26.4 \%$ & $80.7 \%$ & $19.3 \%$ & $78.6 \%$ & $21.4 \%$ \\
\hline Chi-square & $13.9^{* *}$ & & $13.5^{* *}$ & & $28.1^{* * *}$ & \\
\hline
\end{tabular}

${ }^{* *} p \leq .01 ; * * * 0.001$ 


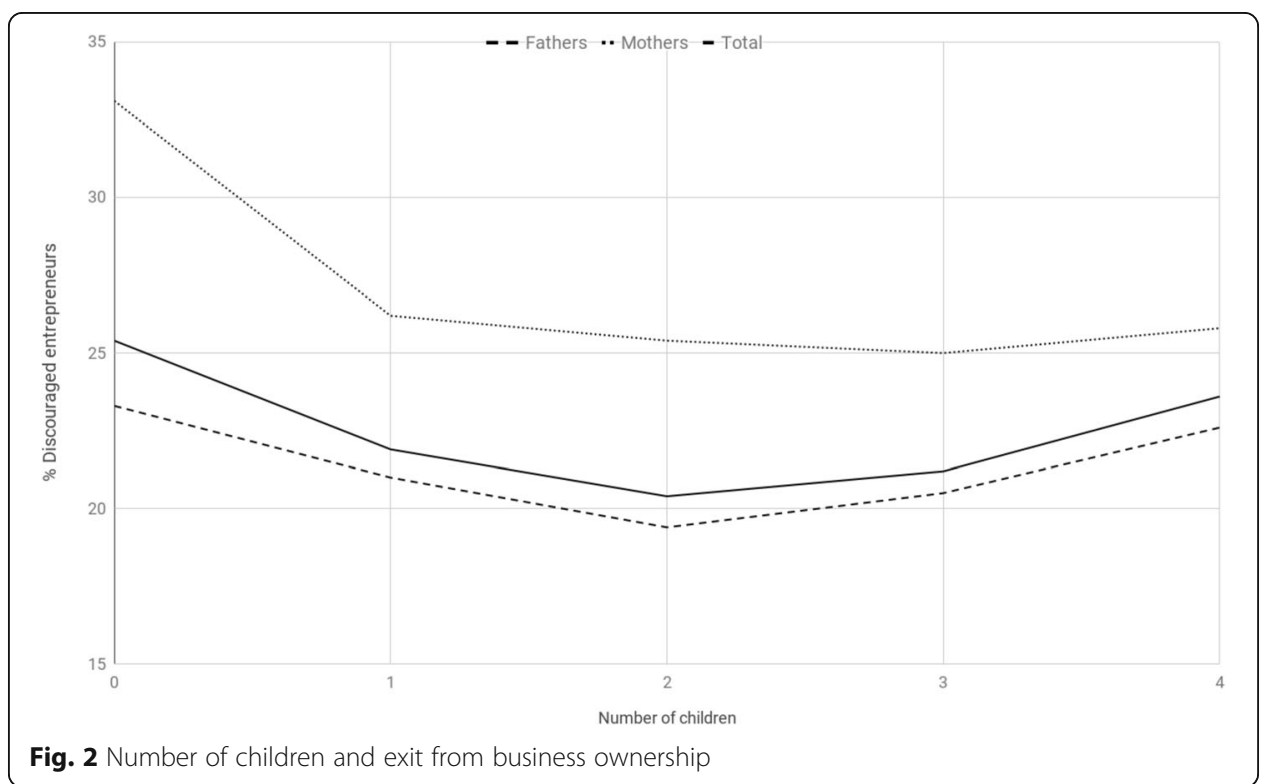

shows the result for women, the second column the result for men, and the third column the result for the entire sample of business owners. In all three logistic regressions, the number of children is negatively and significantly associated with the odds of exit from business ownership while the number of children squared is significantly positively associated with the odds of exit from business ownership, i.e., becoming a discouraged entrepreneur. These results indicate a U-shaped relationship between the number of children and the odds of exit from business ownership for women as well as men. Hypotheses $2 \mathrm{a}$ and $2 \mathrm{~b}$ are supported.

Table 4 Descriptive statistics and correlations among the analysis variables

\begin{tabular}{llllllllllllll}
\hline & Mean & SD & 1 & 2 & 3 & 4 & 5 & 6 & 7 & 9 & Mean & SD \\
\hline 1. Male & .559 & - & 1 & -.015 & .142 & .176 & -.020 & .033 & .078 & -.058 & .830 & .38 \\
2. Age & 39.93 & 6.36 & -.025 & 1 & .182 & -.030 & .011 & .014 & -.081 & .013 & 38.57 & - \\
3. Income & 509,237 & 281,714 & .286 & .110 & 1 & .028 & .116 & .018 & .039 & -.049 & 717,606 & 603,481 \\
$\begin{array}{l}\text { 4. Employed in } \\
\text { a corporation }\end{array}$ & .487 & - & .324 & -.075 & .127 & 1 & -.057 & .052 & -.004 & -.016 & .735 & - \\
$\begin{array}{l}\text { 5. Residence } \\
\text { in Oslo }\end{array}$ & .259 & - & .047 & -.003 & .106 & .060 & 1 & -.070 & -.031 & .019 & .277 & - \\
$\begin{array}{l}\text { 6. Born in } \\
\text { Norway }\end{array}$ & .929 & - & -.011 & .017 & .012 & .004 & -.080 & 1 & -.020 & -.037 & .933 & - \\
$\begin{array}{l}\text { 7. Number } \\
\text { of children }\end{array}$ & 1.62 & .96 & .124 & -.247 & .058 & .015 & -.014 & -.041 & 1 & -.014 & 1.80 & .93 \\
$\begin{array}{l}\text { 8. Business } \\
\text { ownership }\end{array}$ & .045 & - & .121 & -.045 & .167 & .109 & .010 & .003 & .041 & - & - & - \\
$\begin{array}{l}\text { 9. Discouraged } \\
\text { entrepreneur }\end{array}$ & - & - & - & - & - & - & - & - & - & 1 & .214 & -
\end{tabular}

The descriptive statistics on the left and the correlations in the lower left triangle concern the entire sample $(n=$ $685,612)$. All correlations are statistically significant at $p \leq .05$ (two-tailed). The descriptive statistics on the right and the correlations in the higher right triangle concern business owners ( $n=28,127)$. Correlations $\geq .014$ are statistically significant at $p \leq .05$ (two-tailed) 
Table 5 Prediction of entry into business ownership

\begin{tabular}{llll}
\hline & Women $(n=302,839)$ & Men $(n=383,223)$ & Total $(n=685,612)$ \\
\hline Male & - & - & $2.512^{* * *}$ \\
Age & $.969^{* * *}$ & $.959^{* * *}$ & $.960^{* * *}$ \\
Income & $1.000^{* * *}$ & $1.000^{* * *}$ & $1.000^{* * *}$ \\
Employed in a corporation & $2.227^{* * *}$ & $2.044^{* * *}$ & $2.214^{* * *}$ \\
Residence in Oslo & $1.010 \mathrm{~ns}$ & $.916^{* * *}$ & $.941^{* * *}$ \\
Born in Norway & $.815^{* * *}$ & $1.147^{* * *}$ & $1.069^{* *}$ \\
Number of children & $1.170^{* * *}$ & $1.081^{* * *}$ & $1.095^{* * *}$ \\
Number of children & $.992 \mathrm{~ns}$ & $1.004 \mathrm{~ns}$ & $1.002 \mathrm{~ns}$ \\
-2 log likelihood & & 177,697 & 226,252 \\
Cox and Snell $R^{2}$ & & .026 & .034 \\
Negelkerke $R^{2}$ & & .067 & .111 \\
\hline
\end{tabular}

ns not significant

${ }^{* *} p \leq .01 ;{ }^{* * *} p \leq .001$

\section{Discussion}

The findings indicate that there are large gender differences in the odds of becoming a business owner as well as in endured business ownership. Men are much more likely to become a majority owner of a business than women, and women who become business owners are much more likely to give up their entrepreneurial careers than men. Some of these differences can be explained by the preferred employment status among women and men. One Norwegian study from 2015 found that $24.6 \%$ of employed men and $16.9 \%$ of employed women preferred to be self-employed and that $22.5 \%$ of self-employed men and $37.7 \%$ of self-employed women preferred to be employed (Kolvereid 2017). We can therefore expect a higher proportion of males than females to become business owners and a higher proportion of discouraged entrepreneurs among women than among men. However, employment status preferences alone are not sufficient to explain why women only represent $16.4 \%$ of new business owners and as much as $26.4 \%$ of discouraged entrepreneurs.

Given these gender differences in the propensity to become entrepreneurs and discouraged entrepreneurs, it is interesting to note that the effect of the number of

Table 6 Prediction of exit from business ownership

\begin{tabular}{llll}
\hline & Women $(n=4782)$ & Men $(n=23,345)$ & Total $(n=28,127)$ \\
\hline Male & - & - & $.761^{* * *}$ \\
Age & $1.014^{*}$ & $1.006^{*}$ & $1.008^{* * *}$ \\
Income & $1.000^{* * *}$ & $1.000^{* * *}$ & $1.000^{* * *}$ \\
Employed in a corporation & $.973 \mathrm{~ns}$ & $1.009 \mathrm{~ns}$ & $.990 \mathrm{~ns}$ \\
Residence in Oslo & $1.109 \mathrm{~ns}$ & $1.150^{* * *}$ & $1.133^{* * *}$ \\
Born in Norway & $.970 \mathrm{~ns}$ & $.687^{* * *}$ & $.744^{* *}$ \\
Number of children & $.758^{* *}$ & $.919^{*}$ & $.895^{* *}$ \\
Number of children & $1.070^{* *}$ & $1.018^{*}$ & $1.023^{* *}$ \\
-2 log likelihood & 5482 & 23,475 & 28,984 \\
Cox and Snell $R^{2}$ & .011 & .005 & .008 \\
Negelkerke $R^{2}$ & .015 & .008 & .012 \\
\hline
\end{tabular}

ns not significant

${ }^{*} p \leq .05 ;{ }^{* *} p \leq .01 ;{ }^{* * *} p \leq .001$ 
children in the household on entrepreneurship appear to be the same for men and women. Having children and the number of children increase the propensity to become a business owner among women as well as men. The multivariate analyses show that the relationship between the number of children at home and the odds of becoming a business owner is positive and linear for both women and men. Having two or three children is associated with increased odds of continuing an entrepreneurial career among women as well as men, and the multivariate analyses confirm that the association between the number of children and exit from business ownership is non-linear and U-shaped.

\section{Limitations}

This study has several limitations, which open avenues for further research. The dependent variable is majority ownership in at least one limited liability business. This variable is different from measures of entry and survival commonly used in entrepreneurship research, such as new business formation, business survival, and survival as self-employed. We have only monitored majority ownership in limited liability companies. Therefore, we have disregarded other forms of businesses (e.g., sole proprietorships and partnerships). It is possible that some of the business owners are not actively engaged in managing the business. It is also possible that some of the discouraged entrepreneurs identified here have not exited from entrepreneurship but simply reduced their ownership share. Other limitations are that we did not monitor changes in the number of children or gender after 2004 and that we have made no distinction between businesses started from scratch and acquisitive entries. Readers should also be reminded that single mothers are more common than single fathers and that such difference may contribute to the gender gap in entrepreneurship. Finally, we have made no distinction between voluntary and involuntary exit from business ownership, and this study can say nothing about business performance or growth. This is important, as previous research has shown that family size can have different impacts on the performance of businesses owned by women and men (Collins-Dodd et al. 2004; Hundley 2000).

\section{Conclusion}

The findings reported here with regard to the positive association between the number of children and the odds of becoming a business owner is quite robust. The relationship between the number of children and exit from business ownership is not particularly strong, but the findings indicate a U-shaped relationship between the two variables.

\section{Implications}

The results of this study clearly indicate that the size of the household brood is a poor explanation of the gender gap in entrepreneurship. The present study finds the gender gap in entrepreneurship to be larger between men and women without children than between fathers and mothers. The number of children in the household has a positive effect on entrepreneurship among men as well as women. Adults without children are far less likely to become business owners and far more likely to exit from business ownership than mothers and fathers. Prospective entrepreneurs in small families should be aware that future options might tempt them to exit from business ownership. Similarly, prospective entrepreneurs in large families should consider whether family obligations 
might prevent them from continuing their careers as business owners. In western countries, a policy that encourages people to become parents and parents to have more children will also encourage entrepreneurship. Moreover, governments should consider different mechanisms that can help entrepreneurs in large families to remain business owners. Such government intervention can concern assistance directed at the children in the family as well as the business.

\section{Endnotes}

${ }^{1}$ It is probably also correct that the more adults in the household, the less time each adult have to spend on childcare, ceteris paribus. The time available for an adult in a healthy household to work is therefore likely to be a function of the number of adults and the number of children in the household.

${ }^{2}$ The tax authority registers children under 18 years of age for which guardians (not necessarily parents) have an economic responsibility. Not all of these children need to live in the household.

\section{Abbreviation}

GEM: Global Entrepreneurship Monitor (see www.gemconsortium.org)

\section{Acknowledgements}

I am deeply grateful to the Norwegian Tax Authority ("Skatteetaten") for providing the data that made this research possible.

Availability of data and materials

I do not have permission to share the data.

Author's contributions

The author read and approved the final manuscript.

Authors' information

Lars Kolvereid (MSc, MBA, Ph.D.) is a professor of entrepreneurship at Nord University Business School, 8049 Bodø, Norway.

\section{Competing interests}

The author declares that he has no competing interests.

\section{Publisher's Note}

Springer Nature remains neutral with regard to jurisdictional claims in published maps and institutional affiliations.

Received: 31 May 2018 Accepted: 2 August 2018

Published online: 07 September 2018

\section{References}

Aguiar, M, \& Hurst, E. (2007). Measuring trends in leisure: the allocation of time over five decades. The Quarterly Journal of Economics, 122(3), 969-1006.

Aldrich, HE, \& Cliff, JE. (2003). The pervasive effects of family on entrepreneurship: toward a family embeddedness perspective. Journal of Business Venturing, 18(5), 573-596.

Arai, AB. (2000). Self-employment as a response to the double day for women and men in Canada. Canadian Journal of Economics/Revue Canadienne D'Économique, 37(2), 125-142.

Becker, GS. (1965). A theory of the allocation of time. The Economic Journal, 75(299), 493-517.

Caputo, RK, \& Dolinsky, A. (1998). Women's choice to pursue self-employment: the role of financial and human capital of household members. Journal of Small Business Management, 36(3), 8-17.

Carr, D. (1996). Two paths to self-employment? Women's and men's self-employment in the United States, 1980. Work and Occupations, 23(1), 26-53.

Collins-Dodd, C, Gordon, IM, Smart, C. (2004). Further evidence on the role of gender in financial performance. Journal of Small Business Management, 42(4), 395-417.

Connelly, R. (1992). Self-employment and providing child care. Demography, 29(1), 17-29.

Cowling, M, \& Taylor, M. (2001). Entrepreneurial women and men: two different species? Small Business Economics, 16(3), 167175.

Craig, L, \& Mullan, K. (2011). How mothers and fathers share childcare: a cross-national time-use comparison. American Sociological Review, 76(6), 834-861. 
Edwards, LN, \& Field-Hendrey, E. (2002). Home-based work and women's labor force decisions. Journal of Labor Economics, 20(1), 170-200

Fagforbundet. (2004). Triffoppgjøret 2004, Tariff-info 2004, no. 4. Accessed 7 June 2017 from: http://www.google.no/url?sa= t\&rct=j\&q=\&esrc=s\&source=web\&cd=1\&ved=0ahUKEwj7iNScyavUAhWDA5oKHTSCC9QQFggiMAA\&url= http\%3A\%2F\%2Fwww.fagforbundet.no\%2Ffile.php\%3Fid\%3D821\&usg=AFQjCNG6rfW8V3IQ8rZZIKs31LXUXZ4LLeg

Folta, TB, Delmar, F, Wennberg, K. (2010). Hybrid entrepreneurship. Management Science, 56(2), 253-269.

Friedman, D, Hechter, M, Kanazawa, S. (1994). A theory of the value of children. Demography, 31(3), 375-401.

Gundry, LK, Kickul, JR, lakovleva, T, Carsrud, AL. (2014). Women-owned family businesses in transitional economies: key influences on firm innovativeness and sustainability. Journal of Innovation and Entrepreneurship, 3(8), 3-17.

Halket, J, \& Vasudev, S. (2014). Saving up or settling down: home ownership over the life cycle. Review of Economic Dynamics, $17(2), 345-366$.

Hundley, G. (2000). Male/female earnings differences in self-employment: the effects of marriage, children, and the household division of labor. Industrial and Labor Relations Review, 54(1), 95-114.

Joona, PA. (2017). Are mothers of young children more likely to be self-employed? The case of Sweden. Review of Economics of the Household, 15(1), 307-333.

Justo, R, \& DeTienne, DR. (2008). Family situation and the exit event: an extension of threshold theory. Frontiers of Entrepreneurship Research, 28, 1-13.

Justo, R, DeTienne, DR, Sieger, P. (2015). Failure or voluntary exit? Reassessing the female underperformance hypothesis. Journal of Business Venturing, 30(6), 775-792.

Kalnins, A, \& Williams, M. (2014). When do female-owned businesses out-survive male-owned businesses? A disaggregated approach by industry and geography. Journal of Business Venturing, 29(6), 822-835.

Kolvereid, L. (2017). Få drømmer om en karriære som gründer. Magma, 20(8), 24-27.

Kuhn, PJ, \& Schuetze, HJ. (2001). Self-employment dynamics and self-employment trends: a study of Canadian men and women 1982-1998. Canadian Journal of Economics/Revue Canadienne D'Économique, 34(3), 760-784.

Lechner, C, Kirschenhofer, F, Dowling, M. (2016). The influence of social capital on opportunity emergence and exploitation: a comparison of portfolio and serial entrepreneurs. Journal of Innovation and Entrepreneurship, 5(28), 1-23.

Lombard, KV. (2001). Female self-employment and demand for flexible, nonstandard work schedules. Economic Inquiry, 39(2), 214-237.

MacPherson, DA. (1988). Self-employment and married women. Economics Letters, 28(3), 281-284.

McManus, PA. (2001a). Pathways into self-employment in the United States and Germany. Vierteljahrshefte zur Wirtschaftsforschung, 70(1), 24-30

McManus, PA. (2001b). Women's participation in self-employment in western industrialized nations. International Journal of Sociology, 31(2), 70-97.

Noorderhaven, N, Thurik, R, Wennekers, S, Stel, AV. (2004). The role of dissatisfaction and per capital income in explaining selfemployment across 15 European countries. Entrepreneurship Theory and Practice, 28(5), 447-466.

Noseleit, F. (2014). Female self-employment and children. Small Business Economics, 43(3), 549-569.

Olson, PD, Zuiker, VS, Danes, SM, Stafford, K, Heck, RK, Duncan, KA. (2003). The impact of the family and the business on family business sustainability. Journal of Business Venturing, 18(5), 639-666.

Patrinos, HA, \& Psacharopoulos, G. (1997). Family size, schooling and child labor in Peru - an empirical analysis. Journal of Population Economics, 10(4), 387-405.

Rodriguez, P, Tuggle, CS, Hackett, SM. (2009). An exploratory study of how potential "family and household capital" impacts new venture start-up rates. Family Business Review, 22(3), 259-272.

Rønsen, M. (2014). Children and family: a barrier or incentive to female self-employment in Norway? International Labour Review, 153(2), 337-349.

Statistics Norway. (2018). Flest menn starter foretak, men kvinnene følger etter. Etablerere i næringslivet. Accessed 18 Apr 2018 from: https://www.ssb.no/virksomheter-foretak-og-regnskap/artikler-og-publikasjoner/flest-menn-starter-foretak-menkvinnene-folger-etter

Wellington, AJ. (2006). Self-employment: the new solution for balancing family and career? Labour Economics, 13(3), 357-386.

\section{Submit your manuscript to a SpringerOpen ${ }^{\circ}$ journal and benefit from:}

- Convenient online submission

- Rigorous peer review

- Open access: articles freely available online

- High visibility within the field

- Retaining the copyright to your article

Submit your next manuscript at $\boldsymbol{\nabla}$ springeropen.com 